\title{
Audiovisual History
}

Histospheres make history sensuously and experienceable through a complex interplay of visual and aural elements not reducible to a simple stimulus-response model. By utilizing several different sensory channels at once, historical films create a synesthetic reality effect that cannot be broken down into its individual components. Nonetheless, it still makes sense to consider relevant theories of visual and audio history whose ontologies a histosphere absorbs and elaborates. The first section of this chapter surveys the relatively new field of visual history, supplemented by some reflections on the cinematic movement image. I argue that a histosphere creates not just disparate images but a visual sphere in which history is brought to life. Research into audio history, especially the history of film sound, is an even newer and less developed field. In the second section, I therefore sketch the outlines of an audio history of film, and examine the aesthetics and function of film sound, understood as an equally important expressive dimension of histospheres. The two aspects are brought together in the third section: In the perceptual mode of audiovision, film images and film sounds model an internally consistent spatiotemporal structure that can be synesthetically experienced and stands in a referential relation to the past. I suggest that this fusion of sound and vision makes the historical film not just a model of a historical world, but a form of perception in its own right. Consequently, a histosphere is far more than the sum of its visual and aural parts: It is a distinctively cinematic mode of access to history that goes far beyond visual and audio history in isolation.

(C) The Author(s) 2021

R. Greiner, Cinematic Histospheres, https://doi.org/10.1007/978-3-030-70590-9_3 


\section{Visual History}

Early on in SKY WITHOUT STARs, the photograph of a soldier adds an additional historical dimension, supplementing the diegetic present with a personal past. The Wehrmacht uniform, the black ribbon, Anna's wistful expression, the photograph, and its incorporation into the film's world tell a story that emphasizes the role of the individual in the larger historical context of the Second World War.

Although written sources and accounts remain the primary focus in studies of history, the iconic turn has raised awareness of the fact that images also have the potential to constitute reality. Since the late 1990s, a growing number of historians have recognized that "images, whether in the form of films, photographs, or posters, constitute a specific framework of meaning within which people perceive history and construct social meaning." Under the general heading of "visual history," historian Gerhard Paul explores the special role of visual media in the production, communication, and popular understanding of history. He distinguishes several ways in which images can figure in the historian's work: They can be analyzed as sources; they can serve as "mediums" of history; their use in "visual practices" that generate their own realities can be studied; or else the production and distribution conditions of "visual agents and actors" can be investigated. ${ }^{2}$ Increased attention is being paid to visual aspects of history, especially in studies of modern and contemporary history, but some historians still harbor reservations about images, which André Wendler attributes to two problems that have not yet been definitively resolved:

Firstly, there's the question of whether and to what extent images can function as sources and documents, and secondly, there's the question of what information and historiographical knowledge can be found in images and what methods must be used to unlock or apprehend this knowledge. ${ }^{3}$

The methodological uncertainties become more marked when studying moving images. ${ }^{4}$ Visual history centers primarily on photographs, which can be easily archived and analyzed under controlled conditions. Apart from the value of documentary footage as a source, film plays a relatively minor role in historical studies, though as far back as 1947 Siegfried Kracauer's From Caligari to Hitler ${ }^{5}$ attempted to understand the rise of National Socialism through the lens of Weimar Republic cinema. As well 
as their potential for ideological critiques of this kind, films also offer a dynamic aesthetic language that can influence the form and perception of history. The definition of the cinematic movement image ${ }^{6}$ as a meaningful construct of changing image spaces always also involves the dynamics of the spectator's body. Visual history must rise to this challenge. In this connection, Paul notes another potential of cinema that historians have "relatively rarely" paid attention to, namely the moving image's unique ability "to allow people to participate in events either as they happen or retrospectively: its capacity for immersion." I believe that the histosphere model provides the key to theoretical understanding of this aspect. The photograph of the soldier in SKY WITHOUT STARS demonstrates the powerful historical charge images can be given if they are integrated into spectators' reception at an immersive, emotional level. The photograph's simulated historicity-it is black and white and depicts a Wehrmachtsoldier-requires no further clarification. It refers symbolically to the Second World War, which briefly obtrudes into the 1950s setting. Furthermore, the still photograph is integrated into the framing and montage of the film images, allowing it to be experienced as part of the histosphere (Figs. 3.1 and 3.2). Cinematic technology animates the previously static image and reconstitutes its "visibility [...] and perceptual verisimilitude in a difference not of

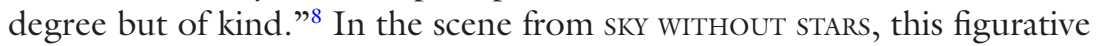
animation is accompanied by literal movement on the screen: The picture on the wall starts to vibrate and, in combination with Anna's pain-filled gaze, awakens associations with wartime air raids. By being included in the histosphere, the photograph's concrete referential level is greatly expanded;

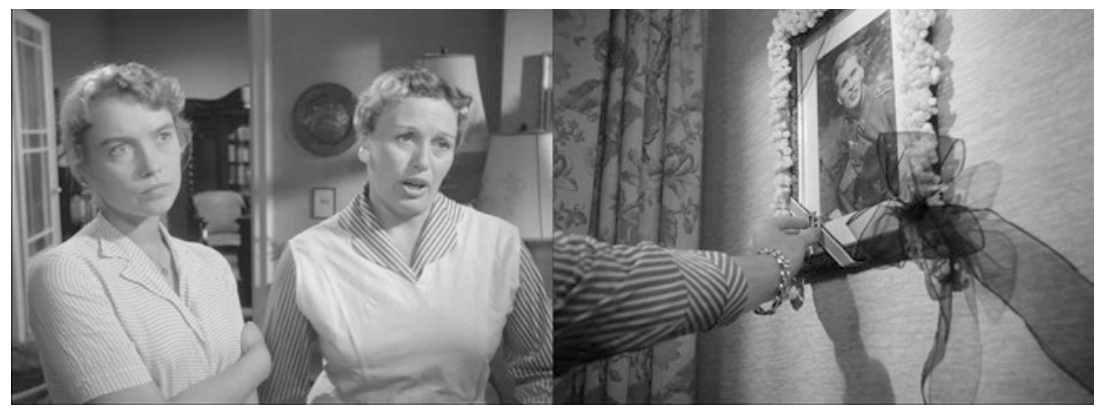

Figs. 3.1-3.2 Incorporation of a photograph into the framing and montage of SKY WITHOUT STARS 
it is not only the subject of the image that becomes significant, but also its meaning for the character in the diegetic present of the 1950s. Here, we see the histosphere not just producing a visible historical cosmos but establishing relations between different historical times.

\section{Audio History}

If we only have the visual level to go on, it will be an inexplicable mystery why the portrait of the soldier suddenly starts shaking in the early scene from SKY WITHOUT STARs. The answer only becomes clear if we also listen to the sound: A loud rumbling noise suggests that the shaking is being caused by a heavy truck outside. This noise also awakens associations with the drone of the bombers that reduced German cities to rubble during the Second World War.

The history of sound and its potential to model history is still a relatively new field of research. Within the discipline of history, a first foray into this area was made by Paul, whose visual history approach had earlier heralded a paradigm shift from the dominance of writing to the dominance of images. With Ralph Schock, he co-edited Sound des Jabrhunderts (Sound of the Century, 2013), ${ }^{9}$ an extensive collection of texts on the cultural and media history of sound, the acoustic history of politics, and the relevance of sound to twentieth-century history of memory. However, just as in earlier work on visual history, film's specific formal features are largely neglected.

In film studies, meanwhile, the 1980s marked the start of increased interest in the topic of sound, which as a discrete dimension of meaning generates what Michel Chion calls "added value." 10 Subsequent work has focused on sound design and the aesthetics and meaning of noise in film. ${ }^{11}$ This was the point of departure for the study Audio History of Film, which explores a field that provides the missing link between film studies, sound studies, and historical studies. ${ }^{12}$ The aim of the study was to "investigate $[\ldots]$ how film sound can generate and shape audiences' experience of history," 13 considering not just the aesthetic dimension of film sound and its potential to produce history, but also its material, technical, and cultural dimensions in relation to models and figurations of history. An example of this can be seen at the start of KU'DAMM 56: Drawn-out tone sequences and resonance effects create a spirited-away atmosphere, helping to situate the action in the past. We see the rooms of the dance school. Monika enters the shot and unpacks her new sneakers. Then a speaker announces 
"Berlin's first rock ' $n$ ' roll championships," thereby locating the scene within a particular historical period. At the same time, percussive rhythms and the sound of cheering spectators set in, creating an air of excited anticipation. Monika races into the crowded venue, where the first couples are already lining up. On the stage in the background, the band is getting ready. A close-up of the first guitar riffs synchronizes the aural and visual levels, and brings the sound of the 1950s rock music to life (Fig. 3.3). But when Monika is flung into the air by her dance partner, transcendent notes underscore the moment's special character and stylize it as a historic event. The audio history of film emphasizes that films create historical experiences not simply through intensely affective images, but also by synesthetically combining images with sound. This idea builds on Vivian Sobchack's phenomenological approach, which understands film in terms of an embodied experience that implicitly also addresses the sense of hearing. ${ }^{14}$ At a narrative level, film sound structures cinematic narration of history by means of continuities and breaks, conjunctions and oppositions. Auditory stimuli are also crucial in determining the mood of a film sequence, by causing spectators to respond emotionally to the depicted historical events and situations. ${ }^{15}$ The "instant credibility" of film sound helps to generate a feeling of authenticity, ${ }^{16}$ while sound design shapes, organizes, and structures the historical cosmos.

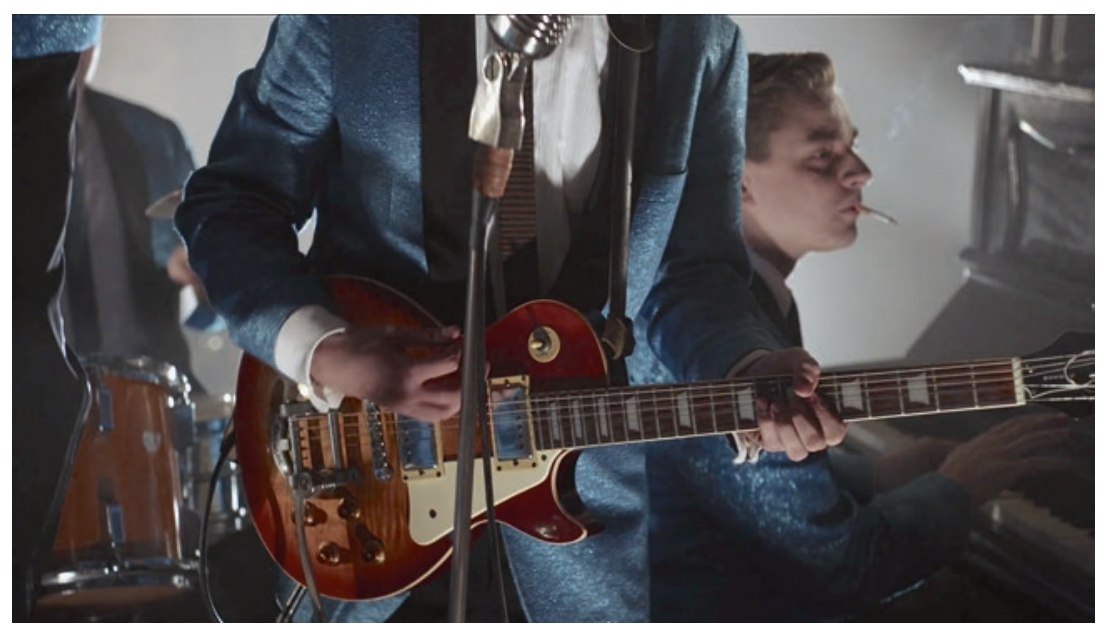

Fig. 3.3 Synchronization of image and sound in KU'DAMм 56 


\section{History as Audiovision}

The clattering and squealing of a subway train. The voice of a young man (Trystan Pütter) breezily reading out a newspaper article about the scenes of mass hysteria and wild excitement at an Elvis concert. We hear a middleaged passenger complaining about this performance, but the young man continues reading. The next stop is announced over the PA system. There is the sound of footsteps, and the young man briefly flirts with two young women, who respond with a slightly amused air. At the same time, the score swells from gentle piano accents to an insistent rhythm. Suddenly, there is a loud roaring sound. This is the information provided to us by the soundtrack. But was that really everything? Let's start again, this time with the images: We are inside a moving subway car. A young man reads a magazine article aloud, annoying an older man. But the man's companion, a friendly old woman in a hat, smiles mischievously. At the same time, a young woman with sad eyes and a suitcase in her hand walks slowly through the car. Nobody appears to notice her except the young man. She pauses by one of the exits and glances at a letter with the handwritten name "Frau Caterina Schöllack" on the envelope. Then she takes a deep breath and opens the sliding doors, even though the train is going at full speed (Figs. 3.4, 3.5, 3.6, and 3.7).

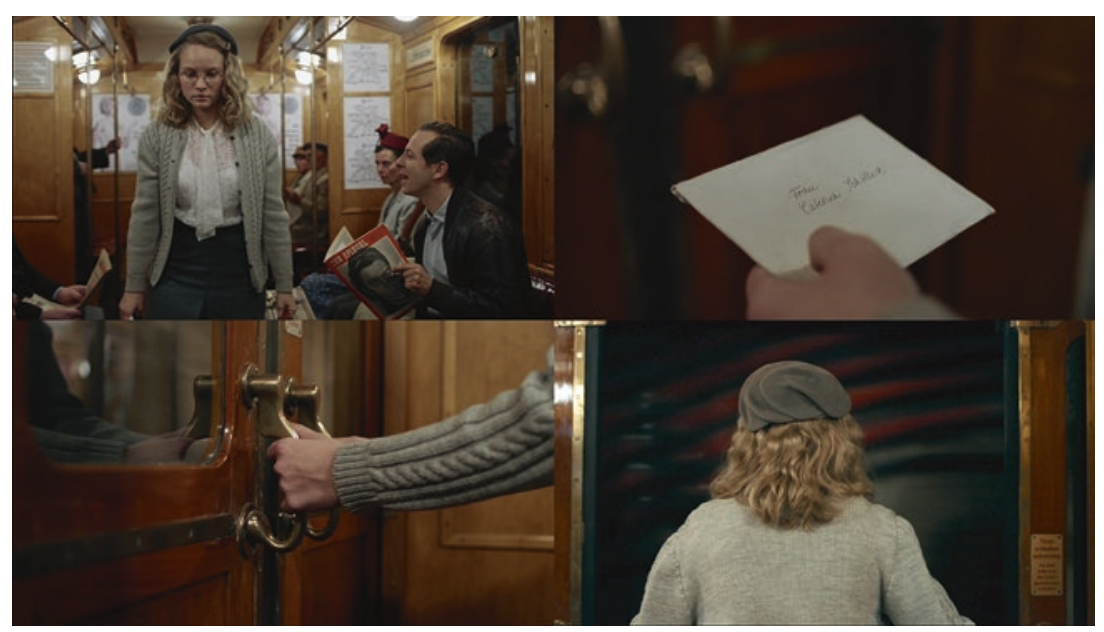

Figs. 3.4-3.7 Subway ride and suicide attempt in KU'DAMм 56 
These may sound like two different films, but in fact they are both the same sequence from KU'DAMM 56, with the focus on auditory perception in the former case and on the visuals in the latter. It is only the combination of the two levels, the jaunty excitement in the young man's voice and the defeated expression of the young woman, the interplay of gazes and the montage, the increasing urgency of the music and the interaction between the characters, that creates an immersive pull, culminating in the climax of the sequence: Monika tries to leap to her death, but Freddy Donath (Trystan Pütter) grabs her. Film image and film sound cannot be separated from each other here, even though they are telling different stories concurrently. Moreover, each mode of perception influences the other: "You do not see the same thing when you hear, and you do not hear the same thing when you see," observes film theorist and composer Michel Chion. ${ }^{17}$ Chion introduced the notion of "audiovision," a fused mode of perception in which sound complements sight with a "series of effects, sensations, and meanings." 18 Valeur ajouté, or "added value," is the "sensory, informative, semantic, narrative, structural, or expressive value that a sound heard in a scene allows us to project onto the image." 19 The combination of the two perceptual levels creates an impression that cannot be found in the image or sound taken alone. ${ }^{20} \mathrm{~A}$ histosphere can likewise be understood as an audiovisual form of perception, whose immersive core lies in the specifically filmic relation between image and sound. In the above-described sequence, Freddy sounds almost euphoric as he recounts the scenes of tumult and excess at the Elvis concert. Monika, by contrast, appears withdrawn and almost apathetic. But when she opens the doors and we can see how fast the train is racing through the dark tunnel, the inner turmoil she is concealing becomes visible. In this sequence, the subway train can be interpreted as a self-reflexive metaphor for the medium of film: At the emotional fracture points where feeling bursts out, the audiovisual excess draws attention to the underlying apparatus that produces it. Monika's suicide attempt transcends the bounds of the narrative. Through the open doors, we see the outside world racing past us like a filmstrip, and we understand that we have embarked with the film character on a journey into the past.

In an essay on "historical sight and hearing," historian Thomas Lindenberger calls for historians to treat audiovision as an object of study with a status equal to writing: 
In order to properly interpret the experiences and stories of today's "colivers" [Mitlebende], they must also be understood as "co-listeners" [Mithörende] and "co-viewers" [Mitsebende]. Their lifeworld has been and continues to be determined by the everyday presence of audiovision, their experience of reality also mediated by the sounds of records and radio, the photographs in magazines, the moving (sound) images in newsreels, feature films, and television. ${ }^{21}$

Conversely, the ubiquity of audiovision implies that history too must find a valid mode of expression for this way of perceiving the world. Histospheres have the potential to fulfill this role. Film images and film sound model historical worlds that we measure against our prior (media) perceptions, and that interfere with and transform our previous conceptions of history. But how a histosphere itself is perceived is also determined by subjective factors. In the very moment of reception, film images and sounds are augmented or overlaid by visual and aural associations. ${ }^{22}$ In the process by which a film makes the past present, a histosphere is not only a figuration of a historical world that can be synesthetically experienced, but also an arena for negotiating conceptions of history. ${ }^{23}$

\section{Notes}

1. Gerhard Paul, "Von der historischen Bildkunde zur Visual History: Eine Einführung," in Gerhard Paul (ed.), Visual History: Ein Studienbuch, Göttingen 2006, p. 29.

2. Gerhard Paul, "Vom Bild her denken: Visual History 2.0.1.6.," in Gerhard Paul, Jürgen Danyel, and Annette Vowinckel (eds.), Arbeit am Bild: Visual History als Praxis, Göttingen 2017, pp. 15-74.

3. André Wendler, Anachronismen: Historiografie und Kino, Paderborn 2014 , p. 86.

4. Ibid.

5. Siegfried Kracauer, From Caligari to Hitler: A Psychological History of the German Film, Princeton 1947.

6. Hermann Kappelhoff defines the movement image as "the meaningful construct of dynamically changing image spaces $[. .$.$] that originates in the$ interaction between media consumers and the moving audiovisual image." Hermann Kappelhoff, Kognition und Reflexion: Zur Theorie filmischen Denkens, Berlin 2018, p. 37.

7. Paul (2017, pp. 57-62). 
8. Vivian Sobchack, "The Scene of the Screen: Envisioning Photographic, Cinematic, and Electronic 'Presence," 2016, https://reframe.sussex. ac.uk/post-cinema/2-1-sobchack/ (last accessed May 1, 2020).

9. Gerhard Paul and Ralph Schock (eds.), Der Sound des Jahrhunderts: Geräusche, Töne, Stimmen 1889 bis heute, Bonn 2013.

10. See Michel Chion, La voix au cinema, Paris 1982; Michel Chion, Le son au cinema, Paris 1985; Michel Chion, Audio-Vision: Sound on Screen, New York 2019; Rick Altman (ed.), Sound Theory, Sound Practice, New York 1992; Volko Kamensky and Julian Rohrhuber (eds.), Ton: Texte zur Akustik im Dokumentarfilm, Berlin 2013.

11. Barbara Flückiger, Sound Design: Die virtuelle Klangwelt des Films, Marburg 2012; Frieder Butzmann and Jean Martin, Filmgeräusch: Wabrnehmungsfelder eines Mediums, Hofheim 2012.

12. See the articles on "Audio History of Film" at https://film-history.org/ approaches/1418 (last accessed May 1, 2020); and Rasmus Greiner and Winfried Pauleit, Nach dem Film 14: Audio History, 2015, www.nachdemfilm.de/issues/no-14-audio-history (last accessed May 1, 2020).

13. Winfried Pauleit, Rasmus Greiner and Mattias Frey, "Audio History of Film: Introduction," 2018, https://film-history.org/approaches/audiohistory-film (last accessed May 1, 2020).

14. See Vivian Sobchack, The Address of the Eye: A Phenomenology of Film Experience, Princeton 1992, p. 4.

15. Michel Chion understands film sound as an "insidious means of affective and semantic manipulation" that "works on us directly, physiologically" as well as influencing our perception. See Chion $(2019$, p. 34), and Rasmus Greiner, "Sonic Histospheres: Sound Design and History," 2018, https:// film-history.org/approaches/sonic-histospheres (last accessed May $1,2020)$.

16. I believe that Roland Barthes's notion of "that-has-been" can be extended from photography to film sound, which is (often incorrectly) assumed to have a direct indexical relation to reality. See Roland Barthes, Camera Lucida: Reflections on Photography, New York 1981, pp. 76-77.

17. Chion (2019, p. xxi).

18. Ibid., p. 203.

19. Ibid., p. 202.

20. Ibid., p. 61.

21. Thomas Lindenberger, "Vergangenes Hören und Sehen: Zeitgeschichte und ihre Herausforderung durch die audiovisuellen Medien," Zeithistorische Forschungen/Studies in Contemporary History 1/2004, www. zeithistorische-forschungen.de/16126041-Lindenberger-1-2004 (last accessed May 1, 2020). 
22. See Sven Kramer, "Recent Appropriations of Documentary Film Material from the Shoah Era," in Delia González de Reufels, Rasmus Greiner, and Winfried Pauleit (eds.), Film and History: Producing and Experiencing History in Moving Images and Sound, Berlin 2015, pp. 32-33.

23. The concept of an arena for negotiation (Arena für Verständigungen) forms the basis for Angela Keppler and Martin Seel's definition of film genres. Inasmuch as a histosphere functions as an arena for negotiation in this sense, generating meaning at the intersection between film and spectator, it can be regarded as a constitutive element of the historical film genre. See Angela Keppler and Martin Seel, "Über den Status filmischer Genres," montage $A V 11: 2,2002$, p. 65.

\section{BIBLIOGRAPHY}

Rick Altman (ed.), Sound Theory, Sound Practice, New York 1992.

Roland Barthes, Camera Lucida: Reflections on Photography, New York 1981.

Frieder Butzmann and Jean Martin, Filmgeräusch: Wahrnehmungsfelder eines Mediums, Hofheim 2012.

Michel Chion, Audio-Vision: Sound on Screen, New York 2019.

Michel Chion, Le son au cinema, Paris 1985.

Michel Chion, La voix au cinema, Paris 1982.

Barbara Flückiger, Sound Design: Die virtuelle Klangwelt des Films, Marburg 2012.

Rasmus Greiner, "Sonic Histospheres: Sound Design and History," 2018, https://film-history.org/approaches/sonic-histospheres (last accessed May 1, 2020).

Rasmus Greiner and Winfried Pauleit, Nach dem Film 14: Audio History, 2015, www.nachdemfilm.de/issues/no-14-audio-history (last accessed May 1, 2020).

Volko Kamensky and Julian Rohrhuber (eds.), Ton: Texte zur Akustik im Dokumentarfilm, Berlin 2013.

Hermann Kappelhoff, Kognition und Reflexion: Zur Theorie filmischen Denkens, Berlin 2018.

Angela Keppler and Martin Seel, "Über den Status filmischer Genres," montage AV 11:2, 2002, pp. 58-68.

Siegfried Kracauer, From Caligari to Hitler: A Psychological History of the German Film, Princeton 1947.

Sven Kramer, "Recent Appropriations of Documentary Film Material from the Shoah Era," in Delia González de Reufels, Rasmus Greiner, and Winfried Pauleit (eds.), Film and History: Producing and Experiencing History in Moving Images and Sound, Berlin 2015, pp. 26-33. 
Thomas Lindenberger, "Vergangenes Hören und Sehen: Zeitgeschichte und ihre Herausforderung durch die audiovisuellen Medien," Zeithistorische Forschungen/Studies in Contemporary History 1/2004, www.zeithistorischeforschungen.de/16126041-Lindenberger-1-2004 (last accessed May 1, 2020).

Gerhard Paul, "Vom Bild her denken: Visual History 2.0.1.6.," in Gerhard Paul, Jürgen Danyel, and Annette Vowinckel (eds.), Arbeit am Bild: Visual History als Praxis, Göttingen 2017, pp. 15-74.

Gerhard Paul (ed.), Visual History: Ein Studienbuch, Göttingen 2006.

Gerhard Paul and Ralph Schock (eds.), Der Sound des Jahrbunderts: Geräusche, Töne, Stimmen 1889 bis heute, Bonn 2013.

Winfried Pauleit, Rasmus Greiner and Mattias Frey, "Audio History of Film: Introduction," 2018, https://film-history.org/approaches/audio-history-film (last accessed May 1, 2020).

Vivian Sobchack, "The Scene of the Screen: Envisioning Photographic, Cinematic, and Electronic 'Presence,"” 2016, https://reframe.sussex.ac.uk/postcinema/2-1-sobchack/ (last accessed May 1, 2020).

Vivian Sobchack, The Address of the Eye: A Phenomenology of Film Experience, Princeton 1992.

André Wendler, Anachronismen: Historiografie und Kino, Paderborn 2014.

\section{Filmography}

Ku'damm 56; dir. Sven Bohse; Germany 2016.

Sky without Stars (Himmel ohne Sterne); dir. Helmut Käutner; Federal Republic of Germany 1955.

Open Access This chapter is licensed under the terms of the Creative Commons Attribution 4.0 International License (http://creativecommons.org/licenses/ by $/ 4.0 /$ ), which permits use, sharing, adaptation, distribution and reproduction in any medium or format, as long as you give appropriate credit to the original author(s) and the source, provide a link to the Creative Commons licence and indicate if changes were made.

The images or other third party material in this chapter are included in the chapter's Creative Commons licence, unless indicated otherwise in a credit line to the material. If material is not included in the chapter's Creative Commons licence and your intended use is not permitted by statutory regulation or exceeds the permitted use, you will need to obtain permission directly from the copyright holder.

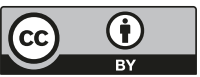

